\title{
Analysis of the Influence of Trust And Service Quality on Customer Value and It's Impact on Customer Satisfaction in Online Shopping Case Study: Lazada Indonesia
}

\author{
Evi \\ Magister Management Student, \\ Mercubuana University, Jakarta, Indonesia \\ Dr. M. Ali Iqbal, M.Sc \\ Senior Lecturer in Magister Management Program, Mercubuana University, Jakarta, Indonesia \\ Dr. Augustina Kurniasih \\ Senior Lecturer in Magister Management Program, Mercubuana University, Jakarta, Indonesia
}

\begin{abstract}
The internet has increased the growth of Internet users quite significantly, The development of internet users has pushed public traffic which will create market potential. The potential of e-commerce in Indonesia is large, easy to see internet access and the population of Indonesia which has begun to be understood and recognizes the process of buying and selling online. The purpose of this study is to analyze the determination of customer value in on line shooping. Sampling is 200 respondents using purposive sampling. The population in this study were Lazada Indonesia customers who had been registered as members of Lazada Indonesia and had transacted at Lazada Indonesia. The results of this study are significant trust in Customer Values, Increased trust will increase Customer Value, Significant Service Quality on Customer Values, Trust increases significantly towards Customer Satisfaction, Service Quality indicates significant Customer Satisfaction, and Customer Value is significant to Customer Customer Satisfaction.
\end{abstract}

Keywords: Customer Trust, Customer Value, Customer Satisfaction, Service Quality, Lazada Indonesia

DOI: $10.7176 / \mathrm{EJBM} / 11-18-06$

Publication date:June $30^{\text {th }} 2019$

\section{INTRODUCTION}

\subsection{Background}

Since 2007, the internet has experienced a significant growth of internet users. The development of internet users is believed to be a shift in the habits of the people who will create a market potential. With this internet can create new opportunities for trading business. The internet can provide a place to market products and services without rental fees. Online shopping is now emerging as a platform called e-commerce, this platform is used by several types of businesses with the aim of getting one market and profit. The company makes a platform application to facilitate purchases so that it can be done regardless of the distance from buyers and sellers, because consumers in one area can easily purchase goods from other areas. Considering, the increasing number of competing platforms, then every platform that exists must give confidence to consumers who will buy the product, because it will be something that consumers will consider. Trust exists when a group believes in the trustworthiness and integrity of partners (Morgan and Hunt, 1994:16)

The introduction of the e-commerce sector in Indonesia is a positive thing, because in total online shopping in Indonesia has doubled since 2014. This phenomenon occurred on the day of national online shopping commonly referred to as Harbolnas on December 12, 2014, and on Harbolnas 2017 total transactions amounting to Rp 4.7 trillion. This amount has increased by Rp. 1.4 trillion compared to 2016, it can be concluded that the Indonesian people have started trying to shop online. The Indonesian Internet Service Providers Association (APJII), noted, as many as $85 \%$ of Indonesian people access the internet via smartphones and 56 percent of internet users shop online with smartphones.

The Indonesian Consumers Foundation, reports that, in 2015, there were reports on online shopping platforms, following a comparison of the ICF case reporting tables table 1.1 Number of Complaints Cases ICF in 2014, which can be seen in 2014 there were no complaints from consumers harm by online shopping platforms. 
Tabel 1.1. Number of Complaint Cases in ICF 2014

\begin{tabular}{lc}
\hline \multicolumn{1}{c}{ Commodity } & Amounth of Cases \\
\hline Banking & 115 \\
Multimedia & 71 \\
Housing & 70 \\
Transportation & 51 \\
Electricity & 48 \\
Leasing & 35 \\
\hline \multicolumn{1}{c}{ Total } & 391 \\
\hline
\end{tabular}

Source: Communication and Information Technology. 2015

In 2015 there have been changes in complaints reports from the public, namely the entry of e-commerce platforms in position 4 , which is explained in table 1.2

Tabel 1.1. Number of Complaint Cases in ICF 2015

\begin{tabular}{lc}
\hline \multicolumn{1}{c}{ Commodity } & Amounth of Cases \\
\hline Banking & 176 \\
Housing & 160 \\
Multimedia & 83 \\
Online shopping & 77 \\
Leasing & 66 \\
Electricity & 58 \\
\hline \multicolumn{1}{c}{ Total } & 620 \\
\hline
\end{tabular}

Source: Communication and Information Technology. 2015

Based on data from ICF, platforms that have received complaints from consumers, namely: Lazada as many as 18 cases, Akulaku 14 cases, Tokopedia as many as 11 cases, Bukalapak as many as 9 cases, Shopee as many as 7 cases and Blibli as many as 5 cases.

Each platform should be able to solve this problem, so that consumers still believe in shopping on that platform. The first thing to pay attention to is a review of products from consumers who have already purchased the product therefore it is needed to conduct a study of determinants of customer satisfaction.

\subsection{Objectives and Research Questions}

The purpose of this study is to develop a model for measuring customer satisfaction online stores in Indonesia that relates to trust, customer quality and customer value. Based on the explanation above, research research can be defined and formulated as follows:

1. Is there an influence between trust in customer value

2. Is there an influence between trust in customer satisfaction

3 . Is there an influence between the quality of service to customer value

4. Is there an influence between the quality of service to customer satisfaction

5 . Is there an influence between customer value on customer satisfaction

\section{THEORETICAL FRAMEWORK AND HYPOTHESES}

\subsection{Trust}

Trust is the belief that one will find what is desired on the exchange partner. Trusts involve a person of willingness to behave in a certain way because of the belief that his partner will give what he or she hopes for and has that the words of someone else's promise or assertion can be trusted by Barnes and Vidgen (2001). According to Kotler and Pfoertsch (2007) "belief is descriptive idea held by someone about something". Trust is a key element of relationship success and linkage trends toward various services and satisfaction assessments felt by customers Arisutha (2005). Trust will occur if someone has confidence in an exchange with partners who have integrity and can be trusted Morgan and Hunt (1994). Agustin and Singh (2005), as perceptions of the benefits enjoyed versus the cost incurred in maintaining an exchange relationship: "[...] the trust increases the intentions of loyalty measure that contributes to the relational value." Dormas et.al (2014) stated that statistically positive values to the relationship of trust were found in the line staff ahead of the company's perceived value, but Laura N (2016) stated that the trust negatively effects and significant with the customer's value.

Mahaputra (2017) states in his research that trust partially has a significant effect on customer satisfaction in the case of BRI Bank. In the process of consumer value formation, Donney and Conno (1997), explain in detail the factors that influence it such as the company's reputation, size, and whether the company can provide security for consumers. On the other hand Murni Y (2018) showed her research that consumer confidence is not significant impact on customer satisfaction, which means that in doing online shopping in Indonesia consumers still lack of confidence in various things. Many consumers claim that the consumer has been tricked into online shopping, this 
could happen as after making a payment for a ordered item never arrives, or the ordered item does not match the seller informed (Starrup Asia, 2013).

\subsection{Service quality}

Pawirosumarto and Liestijati (2017) in their research stated that products, prices, and quality affect direct customer satisfaction. Kotler and Keller (2009) also corroborate this statement, namely by the existence of services that are in accordance with the expectations of consumers, will lead to customer satisfaction. Andreassen and Lidested (1997:21) stated that service quality has an influence on consumer value. Lupiyoadi and Hamdani (2006) stated that one way to create customer satisfaction is to improve service quality, because consumers are the main focus when talking about customer satisfaction. It is said that, the consistency of the quality of products and services can contribute to the success of a company in terms of customer satisfaction. Many previous studies have shown that service quality has a significant influence on customer satisfaction (Lee, 2013).

\subsection{Customer Value}

Kotler (2007) argues that customer value is the difference between total customer value and total customer cost. Berry, et.al (1988) defines that customer value is a thorough assessment of the usefulness of the product or service and what is sacrificed. Mahaputra, (2017) in his research stated that partially customer value had an effect on increasing customer satisfaction of BRI banks. Iqbal et.al (2018) in his research at Mandiri Bank stated that customer value significantly affected satisfaction. Sugiarti T, et al (2013) found that customer value in customer satisfaction in South Kalimantan against 150 Hypermarts. Wang et.al. (2004) found the role of customer value to customer satisfaction, brand loyalty and customer behavior based on CRM performance. Shirazi et.al (2013) found that perceive value had significant effect to customer satisfactionin in their research at cellular-phone customers in Iran "es northeastern city of Mashhad. Furthermore, in separate research carried out by Chitty et al. (2007) and Cronin et al. (2000), it is shown that the perceived value affects customer satisfaction

\subsection{Customer Satisfaction}

Kotler, Keller (2016: 138-139), Satisfaction is the feeling of pleasure or disappointment of a person arising from comparing perceived performance of a product (or outcome) to their expectations. According Tipton F (2010: 147) customer satisfaction is the level of one's feelings after comparing performance he/she felt compared to his/her expectations. Generally, customer expectation is an estimates or beliefs of customers about what will be received when he bought or consume a product (goods or services).

\subsection{Research Model and Hypothesis}

Based on a review of the theories that have been presented before, the research hypothesis is proposed as follows:

H1: Trust affects customer value

H2: Trust influences customer satisfaction.

H3: Service quality affects customer value.

H4: Trust influences customer satisfaction

H5: Customer value influences customer satisfaction

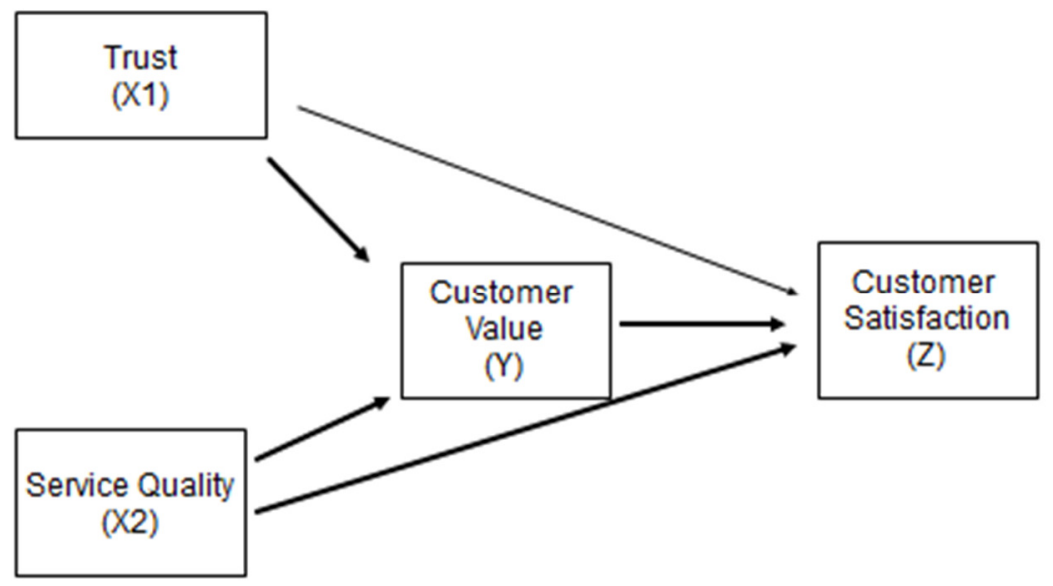

Figure 2.1. Research Framework

\section{METHODOLOGY}

This study uses a type of conclusive research that aims to verify the proposed hypothesis and to test certain correlations. The method of data collection carried out in this study was through questionnaires, interviews and 
documentation. In this study, the population is Lazada Indonesia members who transact and use the Lazada Indonesia platform in the period January 2018 - December 2018. To meet the appropriate sample criteria determined by using SEM depending on the number of indicators used in all latent variables throughout representing the population (Hair JF et al, 2010), namely: Number of samples $=$ Number of indicators $\mathrm{x} 5=39 \mathrm{x}$ $5=195$ respondents and rounded up to 200 respondents. Based on these calculations, the number of samples that must be used is 200 respondents.

In this study, the researcher determined the sampling of 200 respondents using purposive sampling technique, namely sampling in accordance with the requirements or sample requirements of certain populations that are most easily accessible or obtained, namely members of Lazada Indonesia, who have used Lazada Indonesia to shop online. The data used in this study are primary data taken from the results of filling out questionnaires that have been distributed to Lazada Indonesia members.

\section{RESULTS AND DISCUSSION}

After documentation, the results of the validity test and the results presented in Figure 4.1 are obtained:

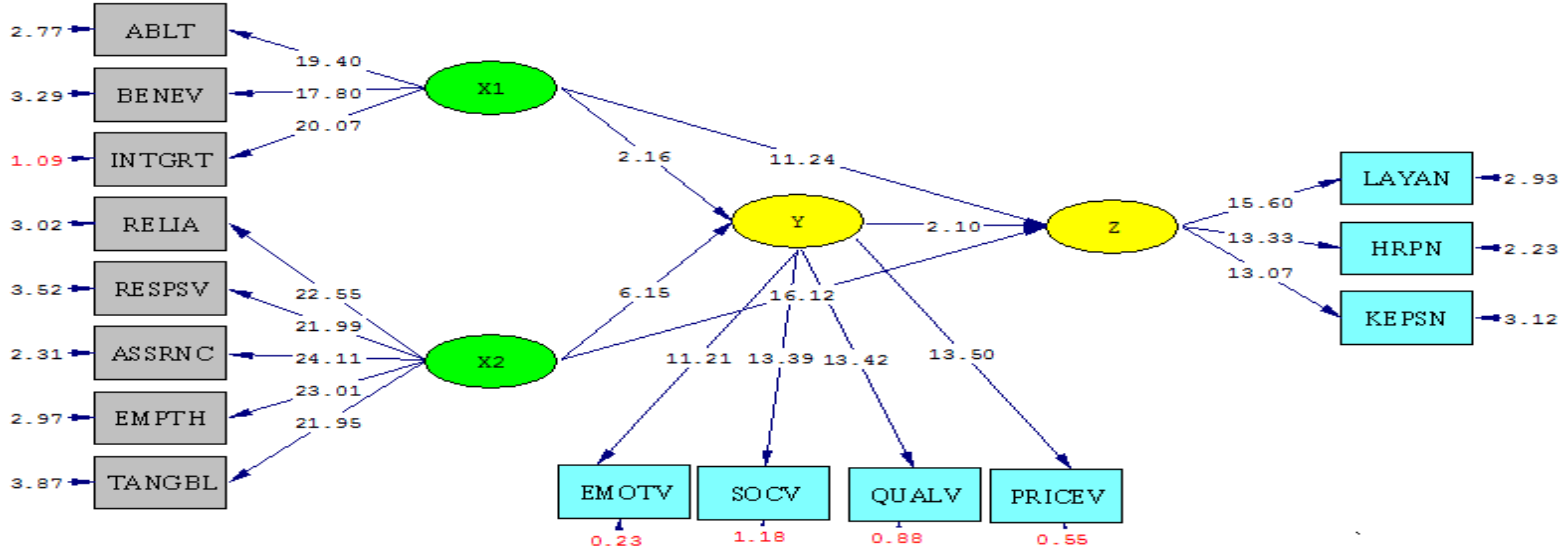

Chi-Square $=224.49, \mathrm{df}=85, \mathrm{P}-\mathrm{value}=0.00000$, RMSEA $=0.051$

Figure 4.1 Standarized Loading Factor

Data Source: Primary Data (2019)

The results of the modification indicate that almost all criteria have been met. For more details the comparison of values can be seen in table 4.1

Table. 4.1. Results of the SEM criteria suitability criteria

\begin{tabular}{|l|l|l|l|}
\hline Goodness-of-Fit & Cutt-off-Value & Results & \\
\hline RMR (Root Mean Square Residual) & $\leq 0,05$ atau $\leq 0,1$ & 0.068 & Good Fit \\
\hline RMSEA (Root Mean square Error of Approximation) & $\leq 0,08$ & 0.051 & Good Fit \\
\hline GFI (Goodness of Fit) & $\geq 0,90$ & 0,91 & Good Fit \\
\hline AGFI (Adjusted Goodness of Fit Index) & $\geq 0,90$ & 0.90 & Good Fit \\
\hline CFI (Comparative Fit Index) & $\geq 0,90$ & 0,98 & Good Fit \\
\hline Normed Fit Index (NFI) & $\geq 0,90$ & 0,98 & Good Fit \\
\hline Non-Normed Fit Index (NNFI) & $\geq 0,90$ & 0,97 & Good Fit \\
\hline Incremental Fit Index (IFI) & $\geq 0,90$ & 096 & Good Fit \\
\hline Relative Fit Index (RFI) & $\geq 0,90$ & 0,95 & Good Fit \\
\hline
\end{tabular}

Source: Data processed by SEM Lisrel (2019)

The second stage, namely reliability testing is done to determine the extent to which the measurement results remain consistent if twice or more measurements are taken of the same object with the same measuring instrument. Next to find out the reliability of the statements in the questionnaire, the Cronbach's technique was used 
Table. 4.2. Validity and Reliability Indicators

\begin{tabular}{|c|c|c|c|c|c|}
\hline Variabel & Indikator & SLF & $\mathrm{Ei}$ & $\mathrm{CR}$ & VE \\
\hline \multirow{3}{*}{$\begin{array}{l}\text { Trust } \\
\text { (X1) }\end{array}$} & Ablt & 0.81 & 0.35 & \multirow{3}{*}{0,718} & \multirow{3}{*}{$0,55 \mathrm{C}$} \\
\hline & Benev & 0.77 & 0.41 & & \\
\hline & Intgrt & 0.92 & 0.15 & & \\
\hline \multirow{5}{*}{$\begin{array}{l}\text { Service Quality } \\
\text { (X2) }\end{array}$} & Relia & 0.80 & 0.36 & \multirow{5}{*}{0,827} & \multirow{5}{*}{0,594} \\
\hline & Respsv & 0.77 & 0.41 & & \\
\hline & Assrnc & 0.85 & 0.28 & & \\
\hline & Empth & 0.81 & 0.35 & & \\
\hline & Tangbl & 0.75 & 0.44 & & \\
\hline \multirow{4}{*}{$\begin{array}{l}\text { Customer } \\
\text { Value } \\
(\mathrm{Y})\end{array}$} & EmotV & 0.98 & 0.03 & \multirow{4}{*}{0,952} & \multirow{4}{*}{0,833} \\
\hline & SocV & 0.92 & 0.15 & & \\
\hline & QualV & 0.94 & 0.12 & & \\
\hline & PriceV & 0.96 & 0.07 & & \\
\hline \multirow{3}{*}{$\begin{array}{l}\text { Customer } \\
\text { Satisfaction } \\
(Z)\end{array}$} & Laynn & 0.81 & 0.34 & \multirow{3}{*}{0,824} & \multirow{3}{*}{0,611} \\
\hline & Hrpn & 0.85 & 0.27 & & \\
\hline & Keps & 0.80 & 0.36 & & \\
\hline
\end{tabular}

Source: Data processed by SEM Lisrel (2019)

Table 4.3. Hyphotesis Test

\begin{tabular}{|l|l|l|l|}
\hline \multicolumn{2}{|c|}{ Hyphotesis } & \multicolumn{1}{c|}{ SLF } & \multicolumn{1}{c|}{ t calculated } \\
\hline H1 & Trust $\rightarrow$ Customer Value & 0.06 & 2.16 \\
\hline H2 & Service Quality $\rightarrow$ Customer Value & 0.16 & 6.15 \\
\hline H3 & Trust $\rightarrow$ Customer Satisfaction & 0.45 & 11.24 \\
\hline H4 & Service Quality $\rightarrow$ Customer Satisfaction & 0.60 & 16.12 \\
\hline H5 & Customer Value $\rightarrow$ Customer Satisfaction & 0.06 & 2.10 \\
\hline
\end{tabular}

Source: Data processed by SEM Lisrel (2019)

\section{FINDING AND DISCUSSION}

Trust has a significant effect on customer value. This can be seen from Table 4.3 the value of the calculated $t$ (2.16) greater than $t$ table (1.96). Coefficient of 0.06 means that if there is an increase in Trust (X1) it will be able to increase Customer Value (Y).

Service quality has a significant effect on customer value. It can be seen from the value of $t$ count (6.15) greater than $t$ table (1.96). The coefficient of 0.16 means that if the service quality is increased, the customer value will increase.

Trust has a significant effect on customer satisfaction. This can be seen from the value of the $t$ count (11.24) greater than $t$ table (1.96). Coefficient of 0.45 means that there is an increase in trust (X1), customer satisfaction will increase.

Service quality has a significant effect on customer satisfaction. This can be seen from the value of the $t$ count (16.12) greater than t table (1.96). The coefficient of 0.60 means that if the quality of service (X2) is increased, customer satisfaction will increase.

Customer value has a significant effect on customer satisfaction. It can be seen from the value of $t$ count (2.10) greater than t table (1.96). Coefficient of 0.06 means that if there is an increase in customer value, the satisfaction that consumers feel will also increase.

\section{CONCLUSION}

\subsection{Practical Implications}

The results show that service quality has the greatest influence on customer satisfaction and also on customer value which means that by increasing the quality of service, customers will increasingly obtain value and be satisfied to shop at the online store. The company can improve the quality of its services through various dimensions including reliability, respect for customers, guarantees, and providing a sense of empathy to its customers.

\subsection{Theoretical Contributions}

Trust has a positive and significant effect on customer value. This result is in line with Agustin and Singh (2005), as perceptions of the benefits enjoyed versus the cost incurred in maintaining an exchange relationship: "[ [...] the trust increases the intentions of loyalty measure that contributes to the relational value." Dormas et.al (2014) stated that statistically positive values to the relationship of trust were found in the line staff ahead of the company's perceived value 
Trust also has a positive and significant effect on customer satisfaction. This is also in line with the research of Mahaputra (2017) which states that trust partially has a significant effect on customer satisfaction in the case of Bank BRI

Service quality has a positive effect on customer value. These results are in line with previous research conducted by Andreassen and Lidested (1997: 21) stated that service quality has an influence on consumer value.

Service quality has a positive and significant effect on customer satisfaction where this result is also in line with previous research conducted by Pawirosumarto and Liestijati (2017) in his research stating that products, prices, and quality affect direct customer satisfaction. Kotler and Keller (2009: 50) also corroborate this statement, namely by the existence of services that are in accordance with the expectations of consumers, will lead to customer satisfaction.

Customer value has a positive and significant effect on customer satisfaction. This result is in line with previous research conducted by Rizki Mahaputra (2017) in his research stating that customer value partially affects the increase in customer satisfaction of BRI banks. Iqbal et.al (2018) in his research at Bank Mandiri stated that customer value significantly affected satisfaction. Sugiarti T, et al (2013) found that customer value in customer satisfaction in South Kalimantan against 150 Hypermarts.

\subsection{Research Limitations}

This study does not include other variables that influence customer satisfaction such as customer loyalty and brand image. In addition, in this study only one type of online store was examined so that it cannot be generalized to the entire online store in Indonesia. As a single point in time, whether conclusions still apply to long-term cannot be determined. A longitudinal study may provide a decisive answer to the question whether the research still applies in the long term.

\subsection{Future Research Direction}

In the future this study will be developed not only to examine one online store, but more than one online store so that the results can be generalized for online stores in Indonesia. This study was conducted at a single point in time. Longitudinal research will have more moments of measurement over time. Companies need to conduct their own research in order to know what is expected by consumers so that they can increase the confidence of consumers when using a product.

\section{References}

Agustin C. and Singh J. (2005). "Curvilinear effects of Consumer Loyalty Determinants in Relational Exchanges", Journal of Marketing Research, Vol. 96, No. 1, pp. 96-108

Andreassen, Wallin \& Lindestad. 1997. The Impact of Corporate Image on Quality, Customer Satisfaction, and Loyalty for Customer with Varying Degrees of Service Expertise. The International Journal of Service Industry Management, 8 (4): 14-15.

Arisutha, D. (2005). Dimensions of Service Quality. Jakarta: Gramedia Pustaka Publishers

Barnes, Stuart and Vidgen Richard.2001. an Integrative Approach to The Assessment of E-Commerce Quality. Journal of Electronic Commerce Research. 3 (3).

Berry, L. L., Parasuraman, A., \& Zeithaml, V. A. (1988). The service-quality puzzle. Business horizons, 31 (5), $35-43$.

Chitty, B., Ward, S., \& Chua, C. (2007). An application of the ECSI model as a predictor of satisfaction and loyalty for backpacker hotels. Marketing Intelligence and Planning, 25(6), 563-580.

Cronin, J. J., Brady, M. K., \& Hult, G. T. (2000). Assessing the effects of quality, value, customer satisfaction on consumer behavioral intentions in service environments. Journal of Retailing, 76(2), 193-218.

Doney, P.M. and Cannon, J. P. (1997), "An Examination of the Nature of Trust in Buyer-Seller Relationship," Journal of Marketing, Vol. 61, pp. 35-51.

Dormas K.B.H, José Marcos Carvalho de Mesquita and Rachel Patrocínio1 (2014). The Relationship between Trust, Value and Loyalty in the Internet Era. Journal of Business and Economics, ISSN 2155-7950, USA June 2014, Volume 5, No. 6, pp. 802-812

Hair, J. F .; Anderson, R. E., Tatham, R. L. and Black, W. C. (2010), Multivariate Data Analysis, 6th ed. Upper Saddle River, New Jersey: Prentice Hall International, Inc.

Iqbal M.A, Niken S and Yanti M (2018). Analysis of the Influence of Brand Image and Customer Value on Customer Satisfaction and Its Impact on Customer Loyalty. International Journal of Economics, Business and Management Research, Vol. 2, No. 04, p 343-355

Kotler, P and K L Keller.(2016), Manajemen Pemasaran, Edisi 13, jilid 1, penerbit Erlangga, Jakarta.

Kotler, Philip. 2007. Marketing Management. Jakarta: PT Malanan Jaya Cemerlang.

Kotler, P and K L Keller.(2016), Manajemen Pemasaran, Edisi 13, jilid 1, penerbit Erlangga, Jakarta.

Kotler, P., \& Pfoertsch, W. (2007). B2B brand management. The Marketing Review, 7 (2), $201-203$. 
Kottler, Philp and K. Lane Keller. 2009. Marketing Management. New Jersey Publisher Prentice Hall

Laura Netty (2016). The Effect of Trust and Service Quality Toward Patient Satisfaction with Customer Value as Intervening Variable Binus Business Review, 7(2), August 2016, 157-162.

Lee, H. S. (2013). Major moderators influencing the relationships of service quality, customer satisfaction and customer loyalty. Asian Social Science, 9(2), 1-11

Lupiyandi Rambat and Hamdi A. 2006. Service Marketing Management, Jakarta: Salemba Empat

Mahaputra, M. Rizky.2017. The Influence of Trust and Customer Value to Customer Satisfaction on Bank BRI Branch Soetomo Jambi. Saudi Journal of Business and Management Studies. Stud .; Vol-2, Iss-8 (Aug, 2017): 737-743

Morgan, R.M. and Hunt, S.D. (1994), "The commitment-trust theory of relationship marketing", Journal of Marketing, Vol. 58 No. 3, pp. 20-38.

Murni Y (2018). Analysis of the Influence of Trust, Easiness in Shopping, Product Quality to Customer Satisfaction to Increaseness in Shopping Customer Loyalty Online Shopping. International Journal of Economics, Business and Management Research, Vol.2, No. 04, p. 61

Pawirosumarto. And Liestijati. 2017. The Effect of Products, Price, And Service Quality on Customer Satisfactionin "Rice for the Poors" Program. RJOS, 12 No 72, December 2017.

Shirazi Ali, Hanzaleh Zeynvand Lorestani and Ahmadreza Karimi Mazidi. Investigating the Effects of Brand Identity on Customer Loyalty from Social Identity Perspective. Iranian Journal of Management Studies (IJMS) Vol.6, No.2, July 2013 pp: 153-178

Starup Asia. (2013), Trust is No.1 in online Shopping in Indonesia, The State Of eCommerce

SugiartiT, Armanu T, Djumilah H and Margono (2013). The Role of Customer Value on the Satisfaction and Loyalty (Study on Hypermart's Customers). International Journal of Business and Management Invention ISSN (Online): 2319 - 8028, Volume 2 Issue 6\| June. 2013 PP.65-70

Tjiptono, F. 2010. Strategi Pemasaran, Edisi Kedua, Penerbit Andi. Yogyakarta.

Wang, Yonggui., Hing, P. L., Chi R., and Yang, Y (2004). An Integrated Framework for Customer Value And Customer Relationship Management Performance: A Customer Based Perspective from China. Managing Service Quality. 14. (2/33), 2004, p. 169-182. 